\title{
Perbandingan Performa Routing Protocol antara Mixed Routing Protocol dengan Single Routing Protocol pada Aplikasi VoIP Menggunakan Riverbed Modeler Academic Edition 17.5
}

\author{
Dewa Nyoman Suartama Ariawan ${ }^{1}$, Gede Saindra Santyadiputra², I Ketut Resika Arthana ${ }^{3}$ \\ 123 Pendidikan Teknik Informatika Fakultas Teknik dan Kejuruan Universitas Pendidikan Ganesha, \\ Jalan Udayana No.11, Singaraja, Bali, 81116 Indonesia \\ e-mail: dewanyomansuartama98@gmail.com¹ $\underline{\text { resika@undiksha.ac.id }{ }^{2}}$ gsaindras@undiksha.ac.id ${ }^{3}$
}

\begin{abstract}
Abstrak
VolP merupakan perangkat teknologi komunikasi yang digunakan oleh perusahaan maupun perumahan untuk dapat melakukan komunikasi. Sejauh ini, ada beberapa kekurangan dari VoIP yang mungkin akan berdampat kepada kondisi riil dilapangan, Sehingga diperlukan adanya kombinasi antar routing protocol yang mampu menutupi kekurangan-kekurangan baik aplikasi VoIP maupun routing protocol tersebut. Penelitian ini bertujuan untuk melakukan penelitian perbandingan performa mixed routing protocol dengan single routing serta melakukan pengujian pada IPv4 dan IPv6 dengan menggunakan topologi semi-mesh dan topologi mesh wireless network pada aplikasi VolP. Penelitian ini menggunakan metode simulasi OPNET Riverbed Modeler Academic Edition 17.5 dengan model desain dan analisis yang meliputi tahapan create network model, modeling, application, profile and failure/recovery config, choose statistics, run simulation, view and analyze the results. Hasil penelitian menunjukkan bahwa kombinasi EIGRP-IGRP-ISIS-OSPF-RIPV2 dan RIPv2-ISIS-EIGRP memberikan hasil penelitian yang baik dan menutupi kelemahan RIPV2, IS-IS dan EIGRP dibandingkan dengan single routing protocol, baik pada topologi semi-mesh dan mesh wireless network.mixed routing protocol. Penambahan variansi perbandingan IPV4 dengan IPv6 berbasis single routing protocol juga menunjukkan hasil yang signifikan, dimana baik IPv4 dengan IPv6 pada topologi semi-mesh dan mesh wireless network berada pada range sebagian berada pada range baik dan sangat baik dengan sisanya adalah hasil cukup, buruk dan sangat buruk.
\end{abstract}

Keywords: Mixed Routing Protocol, Single Routing Protocol, VolP, Semi-Mesh, Mesh Wireless Network, Riverbed Modele

\begin{abstract}
VolP is a communication technology device that is used by companies and homes to communicate. So far, there are several shortcomings of VolP that may impact the real conditions in the field, so it is necessary to have a combination of routing protocols that can cover the shortcomings of both the VoIP application and the routing protocol. This study aims to conduct a comparative study of the performance of mixed routing protocols with single routing and to test IPv4 and IPv6 using semi-mesh topology and mesh wireless network topology in VolP applications. This study uses the OPNET Riverbed Modeler Academic Edition 17.5 simulation method with a design and analysis model that includes the stages of create network model, modeling, application, profile and failure / recovery configuration, choose statistics, run simulation, view and analyze the results. The results showed that the combination of EIGRP-IGRP-ISIS-OSPF-RIPV2 and RIPV2-ISIS-EIGRP provided good research results and covered the weaknesses of RIPV2, IS-IS and EIGRP compared to single routing protocols, both in semi-mesh and wireless mesh topologies. network.mixed routing protocol. The addition of the variance of the comparison between IPV4 and IPv6 based on a single routing protocol also shows significant results, where both IPv4 and IPv6 in the semi-mesh topology and the mesh wireless network are in a range partly in good and very good ranges with the rest being sufficient, bad and very bad.
\end{abstract}


Keywords: Mixed Routing Protocol, Single Routing Protocol, VolP, Semi-Mesh, Mesh Wireless Network, Riverbed Modeler

\section{Pendahuluan}

Sejak hadir di tahun 1995, perkembangan teknologi Voice Over Internet Protocol (VoIP) kini sudah semakin pesat dan cenderung digunakan oleh perusahaan maupun perumahan untuk melakukan komunikasi [1]. Hadirnya VolP dijadikan solusi untuk melakukan komunikasi karena biaya yang dikeluarkan relative murah dan dapat meningkatkan efisiensi pengeluaran [2].

Berdasarkan penelitian yang telah dilakukan, terdapat beberapa kekurangan-kekurangan yang mungkin akan berdampak kepada kondisi riil dilapangan, dimana RIP, EIGRP, dan IS-IS adalah routing protocol yang dianggap lemah dalam aplikasi VoIP. Berdasarkan penelitian yang dilakukan oleh [3] dan [4] menunjukan bahwa RIP memiliki Jitter tinggi dan MOS value yang rendah yang mengakibatkan terjadinya kebisingan yang serius ketika akan memulai percakapan suara. Selain itu, Single routing protocol seperti EIGRP menurut penelitian [5] dan [6] hanya unggul pada aplikasi Database, HTTP dan Email sehingga untuk aplikasi VoIP, EIGRP membutuhkan kombinasi lebih dari 2 (dua) routing protocol untuk dapat berjalan pada aplikasi VoIP dan IS-IS memiliki jitter tinggi terhadap aplikasi VoIP yang akan berdampak kepada kebisingan dan tidak tersampainya paket ke tujuan ketika melakukan komunikasi dibandingkan dengan kombinasi IS-IS/EIGRP, meskipun IS-IS sendiri memiliki keunggulan dalam aplikasi Videoconferencing [7].

Adanya kelemahan pada single routing protocol terhadap parameter yang diujikan baik terhadap aplikasi VoIP maupun aplikasi lainnya dapat diatasi dengan cara mengimplementasikan mixed routing protocol yang merupakan pengambungan 2 (dua), 3 (tiga) atau lebih routing protocol dengan tujuan untuk meningkatkan performasi, kinerja, fleksibilitas, dan efisiensi routing protocol terhadap aplikasi yang akan diujikan pada sebuah penelitian.

implementasi terkait penggunaan mixed routing protocol sudah pernah dilakukan peneliti [5], [6], [7], [8] dan [9]. Namun belum secara spesifik menunjukkan secara detail karakteristik dan penggunaan routing yang lebih bervariasi, Sehingga tujuan dari penelitian ini adalah Untuk mengetahui Perbandingan Performa Routing Protocol antara Mixed Routing Protocol dengan Single Routing Protocol pada aplikasi VolP dengan melibatkan 3 (tiga) skenario yaitu: (1) skenario sesama kombinasi; (2) skenario perbandingan dengan IPv4 dengan IPv6, dan; skenario perbandingan mixed routing protocol dengan single routing protocol.

\section{Metode}

Penelitian ini merupakan penelitian kuantitatif dengan menggunakan metode observasi. Data yang diperoleh dari metode ini meliputi parameter penelitian untuk pengujiannya, penentuan routing protocol, pemilihan topologi, penentuan perangkat dan modul penelitian. Penelitian ini dilakukan dengan bantuan software simulasi OPNET Riverbed Modeler Academic Edition 17.5.

Adapun prosedur simulasi penelitian sebagai berikut.

a. Create Network Setup

Dimulai dari merancang project, menentukan 2 (dua) jenis initial topology yaitu "Create empty skenario" atau "Import from App Transaction Xpert", menentukan skala jaringan, dan Model teknologi yang akan digunakan. Disini model teknologi yang digunakan adalah Cisco, ethernet, internet_toolbox, wireless_lan_adv dan links_PPP meskipun bisa digabungkan dengan model lain diluar model yang sudah ditentukan sebelumnya. Lebih detail dapat dilihat pada Tabel 1 berikut. 
tabel I. Atribut Pembangunan Project Baru

\begin{tabular}{|l|l|}
\hline \multicolumn{1}{|c|}{ Atributes } & \multicolumn{1}{c|}{ Values } \\
\hline Project name & $\begin{array}{l}\text { Perbandingan mixed dengan } \\
\text { single routing protocol }\end{array}$ \\
\hline Skenario name & $\begin{array}{l}\text { (selengkapnya akan dijelaskan } \\
\text { pada sub-bab skenario) }\end{array}$ \\
\hline Initial topology & Create empty scenario \\
\hline Network scale & Office \\
\hline Specify size & $100 \times 100$ \\
\hline $\begin{array}{l}\text { Choose } \\
\text { Technology }\end{array}$ & $\begin{array}{l}\text { Cisco, ethernet, } \\
\text { internet_toolbox, } \\
\text { wireless_lan_adv dan links_PPP }\end{array}$ \\
\hline
\end{tabular}

b. Modeling

Tahapan modelling melibatkan merancang topologi semi-mesh dan mesh wireless network pada Gambar 2 dan 3

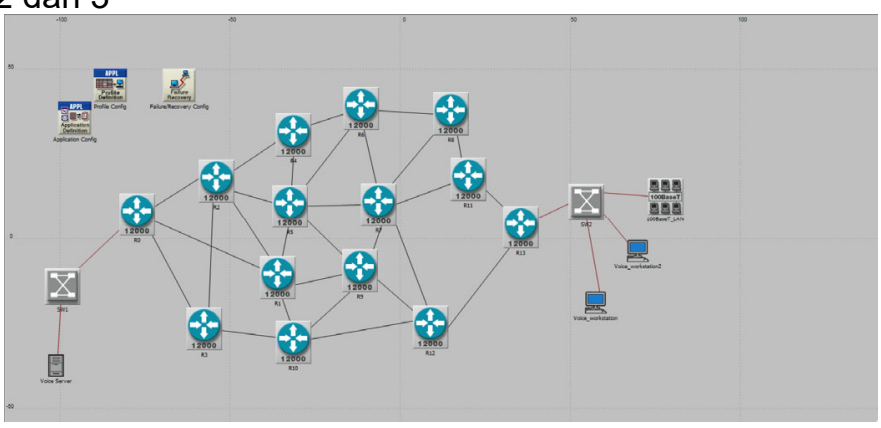

Gambar 2. Perancangan topologi Semi-mesh

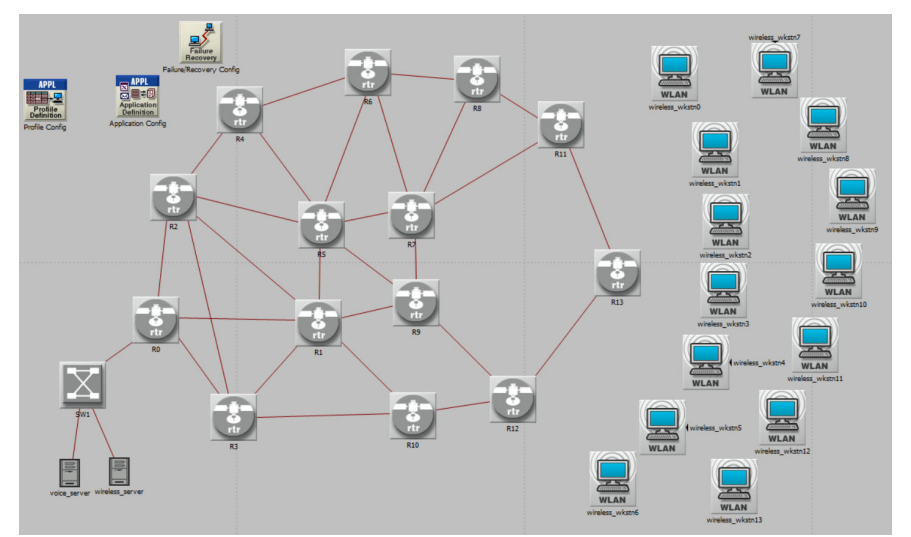

Gambar 3. Perancangan topologi Mesh Wireless Network

Memasang perangkat lain seperti PPP_DS3_link, 100BaseT_link, Ethernet_server, Ethernet16_switch, Ethernet router Cisco 12016 dengan codename CS_12016_16s_a10_fe8_ge3_sl24 dan Cisco 7206 dengan codename CS_7206_6s_aㄹae-8_f4_tr4_slip16, 100BaseT_LAN, Ethernet_wkstn, ip32_cloud, wlan_ethernet_router, wlan_wkstn-adv, memasang mixed routing protocol (EIGRP/IGRP/ISIS/OSPF/RIPV2, OSPF/IGRP/RIPV2, RIPV2/ISIS/EIGRP dan ISIS/IGRP/OSPF), memasang single routing protocol (RIP (Versi 2 dan RIPng), IGRP, EIGRP, OSPF (IPv4 dan OSPFV3), dan IS-IS (IPv4 dan IPv6)), dan membangun skenario. Skenario yang dibangun terdiri atas 12 skenario. 
c. Application, Profile and Failure/Recovery

Application, profile and failure/recover config yang meliputi setup profile dengan nama "Voice Client" dan application config dengan nama "Voice Server" dengan deskripsi PCM Quality and Silence Suppressed, setup failure/recovery pada router yang memiliki jarak terdekat ke tujuan dengan durasi yang sudah ditentukan. Detail failure/recovery dapat dilihat pada Tabel II

TABEL II. KONFIGURASI FAILURE/RECOVERY UNTUK TOPOLOGI SEMI-MESH

\begin{tabular}{|c|c|c|}
\hline Link & Fail & Recover \\
\hline R13 > R12 & 250 & 350 \\
\hline R12 > R9 & 400 & 450 \\
\hline R9 > R1 & 470 & 550 \\
\hline R1 > R0 & 580 & 600 \\
\hline
\end{tabular}

TABEL III. KonfigurAsi FAILURE/ReCOVERY UNTUK TOPOLOGI MESH WIRELESS NetWORK

\begin{tabular}{|c|c|c|}
\hline Link & Fail & Recover \\
\hline $\begin{array}{c}\text { R3 }>\text { Router mesh } \\
7\end{array}$ & 150 & 200 \\
\hline $\begin{array}{c}\text { Router mesh 7 > } \\
\text { R2 }\end{array}$ & 320 & 400 \\
\hline $\begin{array}{c}\text { R2 > Router mesh } \\
\text { 3, }\end{array}$ & 450 & 520 \\
\hline $\begin{array}{c}\text { Router mesh 3 > } \\
\text { R1, }\end{array}$ & 570 & 600 \\
\hline $\begin{array}{c}\text { R1 > Router mesh } \\
6\end{array}$ & 660 & 800 \\
\hline $\begin{array}{c}\text { Router mesh 6 > } \\
\text { R2 }\end{array}$ & 750 & \\
\hline
\end{tabular}

d. Choose Statistics

Parameter statistics yang digunakan untuk menguji Mixed Routing Protocol dengan Single Routing Protocol pada aplikasi VoIP adalah Jitter (sec), MOS Value, Packet Delay Variations, Packet End-to-End Delay (sec), Traffic Received (bytes/sec) dan Traffic Sent (bytes/sec) ditambah dengan parameter QoS seperti Convergence time (sec) dan PPP Throughput (bytes/sec).

e. Run Simulations

Tahapan ini penulis menjalankan simulasi dengan waktu yang sudah dikalkulasi yaitu 60.83 menit melalui konfigurasi "Configure/Run Discrete Event Simulation" dan menjalankannya secara bersamaan melalui "Manage Scenarios" seperti pada Gambar 4 dan 5 sebagai berikut.

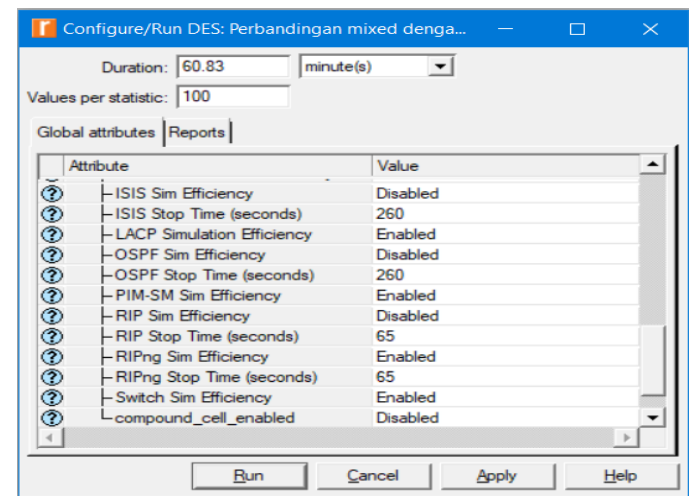

Gambar 4. Tampilan konfigurasi simulasi. 


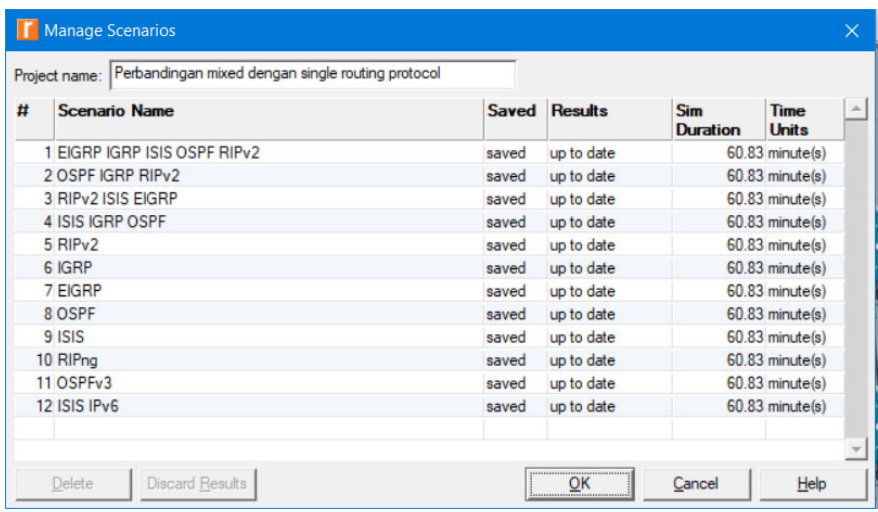

Gambar 5. Memulai simulasi pada Manage Scenario.

f. View and Analyze Results

Setelah simulasi selesai, dilakukan penglihatan grafik atau disebut graphic view dan melakukan analisi hasil yang berupa grafik dan tabel spreadsheet yang didapatkan menggunakan fitur "Export the Graphic to the Spreadsheet".

\section{Hasil dan Pembahasan}

a. Hasil

1. Skenario 4 (empat) kombinasi pada aplikasi VolP

TABEL IV. HASIL SKENARIO 4 KOMBINASI PADA APLIKASI VOIP

\begin{tabular}{|l|l|}
\hline Routing Protocol & Unggul pada \\
\hline EIGRP-IGRP-ISIS-OSPF-RIPV2 & $\begin{array}{l}\text { Convergence time, Jitter, Packet Delay } \\
\text { Variation, Traffic Sent/Received }\end{array}$ \\
\hline RIPv2-ISIS-EIGRP & $\begin{array}{l}\text { Jitter, MOS Value, Packet End-to-end } \\
\text { Delay dan Throughput }\end{array}$ \\
\hline OSPF-IGRP-RIPV2 & MOS Value \\
\hline ISIS-IGRP-OSPF & $\begin{array}{l}\text { Convergence time, Jitter, MOS Value, } \\
\text { Packet Delay Variation dan Throughput }\end{array}$ \\
\hline
\end{tabular}

2. Skenario Perbandingan IPv4 dengan IPv6

TABEL V. Hasil SKenario PERbandingan IPV4 DENGan IPV6

\begin{tabular}{|l|l|}
\hline Routing Protocol & Unggul pada \\
\hline EIGRP & $\begin{array}{l}\text { Convergence Time, Jitter, packet } \\
\text { delay variation, dan traffic } \\
\text { sent/received }\end{array}$ \\
\hline OSPF & Convergence Time dan Jitter \\
\hline IS-IS & Convergence Time dan Jitter \\
\hline RIPV2 & MOS Value dan packet delay variation \\
\hline IGRP & packet end-to-end delay \\
\hline IS-IS IPV6 & $\begin{array}{l}\text { Packet Delay Variation dan Packet } \\
\text { end-to-end delay }\end{array}$ \\
\hline RIPng & $\begin{array}{l}\text { convergence time, jitter, MOS Value, } \\
\text { dan traffic sent }\end{array}$ \\
\hline OSPFv3 & convergence time dan throughput \\
\hline
\end{tabular}


3. Skenario Perbandingan Mixed Routing Protocol dengan Single Routing Protocol secara Keseluruhan

TABEL VI. Hasil Skenario Perbandingan Mixed Routing Protocol dengan Single ROUTING PROTOCOL SECARA KESELURUHAN

\begin{tabular}{|l|l|}
\hline Routing Protocol & Unggul pada \\
\hline EIGRP-IGRP-ISIS-OSPF-RIPV2 & $\begin{array}{l}\text { Convergence time, Jitter, Packet } \\
\text { Delay Variation, Traffic Sent/Received }\end{array}$ \\
\hline RIPV2-ISIS-EIGRP & $\begin{array}{l}\text { Jitter, MOS Value, Packet End-to-end } \\
\text { Delay dan Throughput }\end{array}$ \\
\hline OSPF-IGRP-RIPv2 & MOS Value \\
\hline ISIS-IGRP-OSPF & $\begin{array}{l}\text { Convergence time, Jitter, MOS Value, } \\
\text { Packet Delay Variation dan } \\
\text { Throughput }\end{array}$ \\
\hline EIGRP & $\begin{array}{l}\text { Convergence Time, Jitter, packet } \\
\text { delay variation, dan traffic } \\
\text { sent/received }\end{array}$ \\
\hline OSPF & Convergence Time dan Jitter \\
\hline IS-IS & Convergence Time dan Jitter \\
\hline RIPV2 & MOS Value dan packet delay variation \\
\hline IGRP & packet end-to-end delay \\
\hline IS-IS IPV6 & $\begin{array}{l}\text { Packet Delay Variation, Packet end- } \\
\text { to-end delay }\end{array}$ \\
\hline RIPng & $\begin{array}{l}\text { convergence time, jitter, MOS Value, } \\
\text { traffic sent }\end{array}$ \\
\hline OSPFv3 & convergence time dan throughput \\
\hline
\end{tabular}

Grafik dari tabel hasil penelitian terhadap ke-tiga scenario ini dapat dilihat pada Gambar grafik 6 dan 7 sebagai berikut.

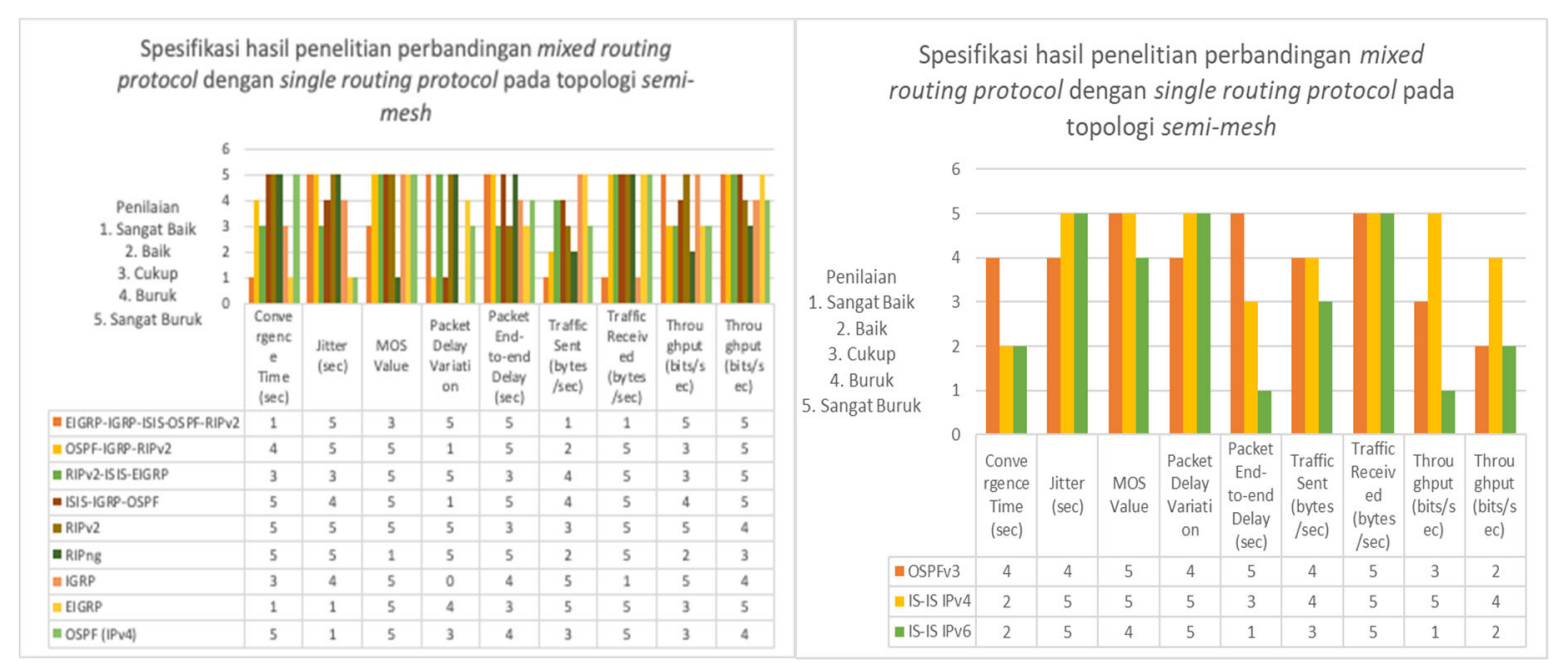

Gambar 6. Grafik spesifikasi hasil penelitian pada topologi semi-mesh 


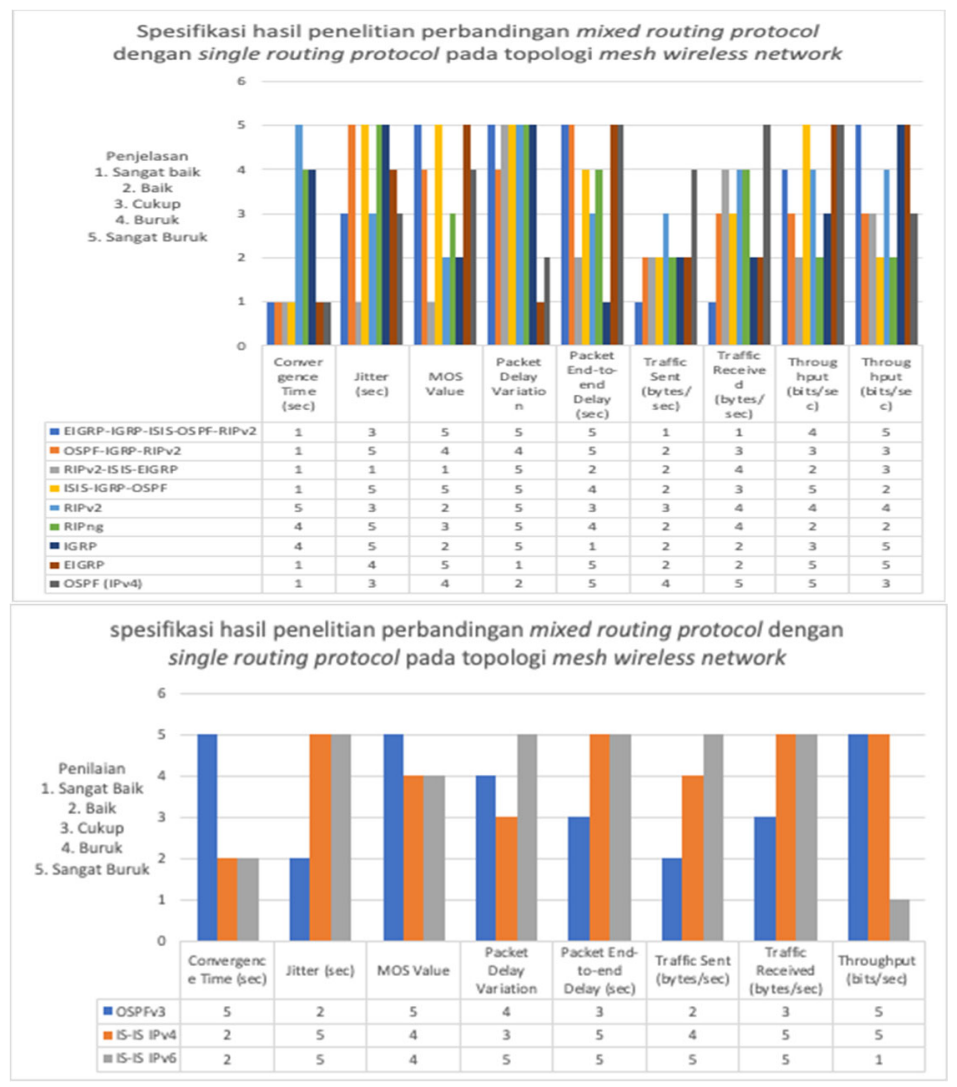

Gambar 7. Grafik spesifikasi hasil penelitian pada topologi mesh wireless network.

b. Pembahasan

a) Pembahasan Hasil Penelitian

1. Hasil pada skenario 4 (empat) kombinasi pada aplikasi VoIP

Penelitian ini menunjukkan bahwa pada perbandingan antar kombinasi, EIGRP-IGRP-ISISOSPF-RIPv2, OSPF-IGRP-RIPV2, RIPV2-ISIS-EIGRP dan ISIS-IGRP-OSPF pada topologi semi-mesh memiliki cukup permasalahan baik pada parameter, metrik, packet format, routing table dan fitur-fitur lainnya yang membuat range parameter berdasarkan pada hasil akhir spreadsheet yang digunakan memberikan hasil yang buruk meskipun kombinasi EIGRP-IGRP-ISIS-OSPF-RIPV2 mengungguli pada topologi semi-mesh dibandingkan dengan kombinasi lain. Sementara itu pada topologi mesh wireless network, kombinasi EIGRP-IGRP-ISIS-OSPF-RIPV2, OSPF-IGRP-RIPV2, RIPV2-ISIS-EIGRP dan ISIS-IGRPOSPF mengalami peningkatan hasil yang signifikan dibandingkan dengan pada topologi semi-mesh. Karena topologi mesh wireless network selain memiliki fitur self-healing dan self-configure, topologi ini juga berinteraksi dengan wifi standar (802.11a, b dan g) seperti hal nya pada jaringan wifi lokal pada umumnya, mempermudah konfigurasi dan semakin banyak router yang terpasang akan semakin cepat jaringan wifi yang dimiliki. Sehingga untuk perbandingan antar kombinasi, kombinas EIGRP-IGRP-ISIS-OSPF-RIPV2 dan RIPV2-ISIS-EIGRP menjadi unggul pada topologi mesh wireless network dibandingkan dengan kombinasi lain.

2. Hasil pada skenario Perbandingan IPv4 dengan IPv6

Berlanjut pada skenario kedua yaitu perbandingan IPv4 dengan IPv6, terlihat pada Tabel 4.23 (a) dan (b) memiliki hasil yang sangat berbeda baik pada topologi semi-mesh maupun mesh wireless network. Hal ini dipengaruhi dari konfigurasi failure/recovery yang cukup 
banyak, membuat routing protocol berbasis IPv4 dan IPv6 harus melakukan kalkulasi ulang agar dapat mengirimkan dan menerima paket suara dengan cepat. Tetapi dari segi penilaian yang didapatkan IPV4 menggunguli pada topologi mesh wireless network, tetapi IPV6 menggunguli pada topologi semi-mesh. Hal tersebut dikarenakan failure/recovery tersebut, IP address yang invalid ataupun konfigurasi yang dilakukan pada setiap router untuk mengatur routing protocol yang akan dipasangkan pada jaringan.

3. Hasil pada skenario Perbandingan Mixed Routing Protocol dengan Single Routing Protocol secara Keseluruhan

Dimana secara keseluruhan, kombinasi EIGRP-IGRP-ISIS-OSPF-RIPV2 dan RIPV2-ISISEIGRP memberikan hasil penilaian yang signifikasi naik lebih baik dibandingkan dengan penelitian sebelumnya. Topologi mesh wireless network memberikan dampak yang sangat berpengaruh dengan hasil penelitian yang didapatkan dibandingkan dengan single routing protocol yang hanya unggul pada topologi semi-mesh, tetapi terlihat sedikit impruviasi pada topologi mesh wireless network selain itu topologi wireless memberikan hasil yang baik untuk mixed routing protocol dibandingkan pada topologi semi-mesh. Mengingat topologi mesh baik semi-mesh dan full mesh berbasis wired memiliki biaya dan redundant yang lebih tinggi dibandingkan dengan topologi lain, serta membutuhkan banyak peralatan dan port untuk dapat terhubung membentuk jaringan topologi. Kelemahan dari topologi mesh sendiri juga diperbesar dari penggunaan failure/recovery yang membuat topologi mesh berkabel lebih sulit untuk berkembang daripada topologi mesh wireless. Sementara itu, topologi mesh wireless memiliki keunggulan pada fitur multi-hops, self-healing dan selfconfigure sehingga permasalahan yang terjadi pada ketahanan dan skalabilitas dapat diatasi dengan fitur tersebut.

\section{Kesimpulan}

Berdasarkan hasil penelitian, dapat disimpulkan bahwa kombinasi EIGRP-IGRP-ISIS-OSPF-RIPV2 dan RIPv2-ISIS-EIGRP memberikan hasil penelitian yang baik dan menutupi kelemahan RIPV2, ISIS dan EIGRP dibandingkan dengan single routing protocol, baik pada topologi semi-mesh dan mesh wireless network. Hal ini dipengaruhi tidak hanya dari skala yang digunakan dan modul/konfigurasi yang digunakan, tetapi parameter juga turut mengambil bagian dari penelitian ini untuk meneliti performasi dan kinerja pada mixed routing protocol yang diujikan dengan single routing protocol dengan parameter yang meliputi: (1) Convergence Time (sec); (2) Jitter (sec); (3) MOS Value; (4) Packet Delay Variations; (5) Packet End-to-end Delay (sec); (6) Traffic Sent (bytes/sec); (7) Traffic Received (bytes/sec); (8) Throughput (bits/sec) $\rightarrow$, dan; (9) Throughput (bits/sec) $\leftarrow$. Selain itu, pada penelitian ini juga menambahkan variansi perbandingan IPv4 dengan IPv6 berbasis single routing protocol dengan skala, modul/konfigurasi dan parameter yang sama menunjukkan hasil yang signifikan, dimana baik IPv4 dengan IPv6 pada topologi semi-mesh dan mesh wireless network berada pada range sebagian berada pada range baik dan sangat baik dengan sisanya adalah hasil cukup, buruk dan sangat buruk. Sehingga secara keseluruhan, dapat peneliti simpulkan bahwa mixed routing protocol dapat menjawab permasalahan dari RIPv2, IS-IS dan EIGRP dibandingkan dengan single routing protocol. Selanjutnya, dapat dikembangkan lebih lanjut dengan mementingkan topologi dengan skala yang lebih luas baik menggunakan topologi berkabel ataupun topologi wireless, pengembangan penelitian kombinasi routing protocol yang melibatkan 4 (empat) kombinasi dengan 5 (lima) kombinasi dan 3 (tiga) kombinasi baik hanya IPv4 saja, IPv6 saja ataupun keduanya menggunakan fitur transisi yang dimiliki oleh Riverbed Modeler dengan parameter yang lebih luas, seperti FTP, HTTP, DB dan Video Conferencing.

\section{Daftar Pustaka}

[1] Forda, G. and Septana, H. D. "Analisis Performansi Voice Over Internet Protocol ( Voip ) Berbasis Session Initiation Protocol ( Sip )" Jurnal Masyarakat Telematika dan Informasi, Vol.5, No.4, p.85-96, (2014). 
[2] HP, W., Susilawati, H. and Noviandono, R. K. "Analisis Performansi VOIP (Voice Over Internet Protocol) Pada Jaringan Wimax" JURNAL INFOTEL - Informatika Telekomunikasi Elektronika, Vol.3, No.1 p.58, (2011).

[3] Che, X. and Cobley, L. J. "VolP performance over different interior gateway protocols", International Journal of Communication Networks and Information Security, Vol.1, No.1, p. 3441, (2009).

[4] Kudtarkar, A., Sonkusare, R. and Ambawade, D. "Performance analysis of routing protocols for Real Time Application", International Journal of Advance Research in Computer and Communication Engineering, Vol.3, No.1, p.-, (2014).

[5] Lemma, E. S., Hussain, S. A. and Anjelo, W. W. "Performance Comparison of EIGRP / IS-IS and OSPF / IS-IS", Electrical Engineering, Vol.-, No.-, p.-, (2009).

[6] Farhangi, S., Rostami, A. and Golmohammadi, S. "Performance comparison of mixed protocols based on EIGRP, IS-IS and OSPF for real-time applications", Middle East Journal of Scientific Research, Vol.12, No.11, p. 1502-1508, (2012).

[7] Farhangi, Sajad and Golmohammadi, S. "A Comparative study of IS-IS and IGRP protocols for real-time application based on OPNET", Advances in Electrical Engineering Systems, Vol.1, No.1, p. 65-70, (2012).

[8] Mohammad, Z., et al. (2017) 'Performance Analysis of Route Redistribution among Diverse Dynamic Routing Protocols based on OPNET Simulation', International Journal of Advanced Computer Science and Applications, Vol.8, No.3, p. 324-332, (2017).

[9] Mohammad, Z., Abusukhon, A. and Al-Maitah, M. A. "A comparative performance analysis of route redistribution among three different routing protocols based on OPNET simulation", International Journal of Computer Networks and Communications, Vol.9, No.2, p. 39-55, (2017).

[10] Bruno, A. and Kim, J. CCDA® Exam Certification Guide (CCDA Self-Study, 640-861), 2nd Edition., City: Cisco, (2003), pp.-

[11] Maryati, L. D., Primananda, R. and Hannats, M. "Analisis Kinerja Protokol Routing OSPF dan EIGRP Untuk Aplikasi VolP Pada Topologi Jaringan Mesh”, Jurnal Pengembangan Teknologi Informasi Dan Ilmu Komputer, Vol.1, No.9, p. 960-970, (2017).

[12] M. Alsahlany, A. and S. Rashid, H. "Audio Codecs Impact on Quality of VolP Based on IEEE802.16e Considering Mobile IP Handover", American Journal of Networks and Communications, Vol.4, No.3, p. 59, (2015).

[13] R. Zopf "Real-time Transport Protocol (RTP) Payload for Comfort Noise (CN)",September (2002). [Online]. Available: https://tools.ietf.org/html/rfc3389.

[14] A. Morton, B. Claise "Packet Delay Variation Applicability Statement", Maret (2009). [Online]. Available: https://tools.ietf.org/html/rfc5481.

[15] Jadhav, S., Zhang, H. and Huang, Z. "Performance evaluation of quality of VolP in WiMAX and UMTS", Parallel and Distributed Computing, Applications and Technologies, PDCAT Proceedings, Vol. - No. June 2015, p. 375-380, (2011).

[16] Sleem, A., Olumuyiwa, O. and Kamel, K. "REAL TIME PERFORMANCE EVALUATION OF VOICE OVER IP CALL QUALITY UNDER Aladdin Sleem Olugbenga Olumuyiwa Khaled Kamel Department of Computer Science Texas Southern University", International Journal of Applied Sicence and Technology, Vol.1, No.6, p. 286-299, (2011).

[17] H. Schulzrinne, S. Casner, R. Frederick, V. Jacobson "RTP: A Transport Protocol for Real-Time Applications", January (1996). [Online]. Available: https://tools.ietf.org/html/rfc1889.

[18] H Miraz, M. et al. "Simulation and Analysis of Quality of Service (QoS) Parameters of Voice over IP (VolP) Traffic through Heterogeneous Networks", International Journal of Advanced Computer Science and Applications, Vol.8, No.7, p. 242-248, (2017).

[19] Vasiliki. Panagiotopoulou, "Simulation-based Comparative Study of OSPF and EIGRP Routing Protocols", Open University of Cyprus, (2015). 